Published on Reviews in History (https://reviews.history.ac.uk)

\title{
Bibliography of the Battle of the Somme: Part 1 [of 2]
}

Review Number: 2000

Publish date: Thursday, 6 October, 2016

Author: Martin Middlebrook

ISBN: 9781473877160

Date of Publication: 2016

Price: $£ 19.99$

Pages: 384pp.

Publisher: Pen and Sword Military

Publisher url:

Place of Publication: Barnsley

Reviewer: Ross Davies

Heinrich Himmler apart, former poultry farmers don't figure much in the bibliography of military history. Martin Middlebrook, however, proves to be the outstanding exception. With this one book, his first, Middlebrook prised open a new window onto Great War studies in general, and in particular onto the 1916 Battle of the Somme. As part of the Somme centenary publishing effort, Pen \& Sword Military republishes the hardback edition of Middlebrook's The First Day on the Somme. Based upon original, indeed groundbreaking, research, The First Day on the Somme has been and remains an entry-point into Somme studies for students ever since first published by Allen Lane in 1971. Penguin cannily holds onto the paperback rights, and that edition has never gone out of print. Now, nearly half a century later, historians - academic or otherwise - continue to draw upon and cite The First Day on the Somme. (1)

Readable as well as founded upon original research and extensive fieldwork, The First Day on the Somme remains a resource for academics. But it also serves as a portal for school students and undergraduates. Some of these young readers become military historians who make further contributions to Great War studies.

Gary Sheffield did:

I have been fascinated by the Battle of the Somme for most of my life. In my early teens I picked up a secondhand copy of of Martin Middlebrook's book The First Day on the Somme and was enthralled and appalled in about equal measure. Enthralled because Middlebrook's brilliant story-telling of the story of 'Kitchener's Mob', a mass citizen army captured my imagination. Appalled because of the terrible casualties suffered by the British Army on 1 July 1916: nearly 60,000 men killed, wounded, missing and taken prisoner, about 20,000 of them fatalities, for apparently so little gain. I wanted to know more, but my locla library in south London did not have much on the subject, and I had to content myself with re-reading The First Day on the Somme several times. Although dated in some ways, it remains essential reading to this day.(2)

When Sheffield went up to Leeds University he took as his special subject 'Britain and the First World War', concentrating in particular on 'Kitchener's Mob', the volunteer citizen-soldiers who bore the brunt of the casualties on 1 July 1916 and the succeeding two and a half months of the Somme campaign. Sheffield's early interest in the Somme reignited, and he came to see The First Day on the Somme as 'one of the 
foundation stones' of his preoccupation with this numinous battle. $\underline{(3)}$

In 1984, and by now a graduate student, Sheffield made the first of what would be many visits to the Somme battlefield. He got what he calls the real 'feel' for the Somme in hunting down the more obscure areas of the battlefield and was haunted by vast stillness of the many Commonwealth War Graves Commission cemeteries:

Serried ranks of headstones, manicured lawns, well-tended flowers - paradoxically, nothing brings home the dreadful nature of the fighting to me more effectively than these idyllic spots, that so well fulfil the original intention of recreating an English country garden overseas.(4)

Middlebrook had felt the same on his first visit to the Somme in 1967. At the time, 'Somme tourism' was slackening as survivors of the carnage and immediate relatives of the fatalities died off. The popular success of The First Day on the Somme, however, awoke fresh interest. Middlebrook now coupled a new career as a prolific military historian of 20th-century war with running battlefield tours. Tony Smith, secretary of The Guild of Battlefield Guides, suggests that over 300,000 people a year now visit the Somme on UK-sourced tours alone. $\underline{(5)}$

Another centenary event is the republication of The Middlebrook Guide to the Somme Battlefields, cowritten with the late Mary Middlebrook. Sheffield was invited to write his 2003 The Somme for Cassell's Fields of Battle series of short studies. The series editor, Richard Holmes - another Sandhurst alumnus commends Sheffield's 'measured operational narrative leavened by the impact of personality', which many see as a Middlebrook hallmark. Of Sheffield, Holmes observes 'how right he is to emphasise what historians owe to Martin Middlebrook's ground-breaking work'.(6) Sheffield covers both 1 July 1916 (the opening day of British and Dominion infantry offensive) and the subsequent course of the Somme campaign in his Forgotten Victory - The First World War: Myths and Realities.(7)

The youthful Sheffield of the 1970s and 1980s was not the first academic of note to be gripped by The First Day on the Somme. In 1976, John Keegan - a predecessor of Sheffield's at Sandhurst - identified Middlebrook's enduring gift to historians of the Great War and of Somme studies, which was to disperse the fog that still cloaked the slaughter of the hastily-raised Kitchener volunteer battalions, amateurs mostly officered by men who had no more preparation than they for the hideous carnage of the 20th-century battlefield. On 1 July, the middle day of the middle year of the Great War, the first day of the British and Dominion infantry offensive, most of the 60,000 casualties (defined by Middlebrook as 'killed, died of wounds, missing, prisoners and wounded') occurred within the first hour or so. This was about half the attacking force, one casualty per 18 inches of line, over 21,000 of these 'casualties' killed or missing. Total German casualties, argued over to this day, are put at about 8,000. Some thousands of the British dead might have lived had front-line rescue, medical and evacuation facilities not been overwhelmed by the unexpectedly huge butcher's bill. As one of Middlebrook's Kitchener respondents observes, some of the wounded awaiting evacuation in their own trenches drowned when heavy rain fell on 2 July.

The first day on the Somme over (the 132nd day of the battle of attrition between the French and Germans at Verdun), the offensive was resumed. It petered out 140 days later in the mid-November rain and mud. By then, total British and Dominion casualties are estimated at 419,654, of whom perhaps 131,000 were dead and missing.

To meet the growing demands of Great Britain's French ally, cracking under the strain of the enemy offensive at Verdun, the civilian soldiers of 'Kitchener's Mob' were rushed to the Somme front half-trained, inadequately supplied with artillery, and directed by generals new to managing war on this scale. Originally, the offensive was to be led by the more experienced and better-equipped French but as Verdun consumed more and more reserves, the French scaled down their commitment to the coming offensive on the Somme, withdrew troops and left the British with a much-extended line, from which to attack a defensive system 20 
miles long and three miles deep. Ironically, the French attack fared better on the first day, their troops (and leadership) being more experienced and backed by more and better artillery per mile of front. The Somme was Britain's introduction to fielding a Continental-style mass army at a time when contemporary generalship, in Keegan's phrase 'was schooled to believe in heavy casualties' while 'a mood of self-sacrifice had the Kitchener armies in its grip'.

Come the day, 1 July, the Kitchener men (and boys) were thrown into the Fourth Army's attack against a battle-hardened, well-entrenched enemy occupying all the high ground. A second- or even third-line German trench could overlook not just the trenches opposite, but fire over the German first line, and in places rake the waves of attacking troops from two or even three directions. Many attackers died making their own way forward to their own first trench.

The Germans had had since late 1914 to excavate defences dug deep enough to ensure enough of the machine-gun teams survived the initial bombardment to emerge from their shelters and re-occupy their own front trenches before their attackers reached them.

The 'first day' on the British and Dominion sector of the Somme followed a week-long bombardment of the German trench and artillery positions by 400 heavy and 1,000 field guns, unprecedented in its ferocity but still insufficient for the increased length of line the French now insisted their ally assault. The British leadership clung to the idea that the shelling would cut the German wire and entomb the first-line defenders, permitting the leading waves of attackers a 'walk-over'. It was not to be. The British were not ready to field the quantity or quality of artillery, shells or trained artillerymen required to knock out the German defenders.

Wave after wave of Kitchener volunteers dutifully plodded up the now corpse-strewn slopes towards uncut barbed wire and unsilenced machine-guns. All this in a battle at a time and in a place that the British commander, Sir Douglas Haig, did not want. There were no railheads or other valauble objectives behind the German trenches on the Somme, and Haig had made his name in the defence of the Ypres salient and wanted to wage the British 1916 campaign to break out of Ypres and recapture Antwerp and other channel ports. Nonetheless, Haig had to defer to the wishes of the French, the superior partner in the war on the Western Front.

In his The Face of Battle (1976) Keegan - then a Senior Lecturer in War Studies at Sandhurst - observes 'Even sixty years later it is very difficult to discover much that is precise, detailed and human about the fate of a great number of the Fourth Army on July 1st'.

Though the analogy is what an academic reviewer would call unhistorical, there is something Treblinka-like about almost all accounts of July 1st, about those long lines of young men, shoddily uniformed, heavily burdened, numbered about their necks, plodding forward across a featureless landscape towards their own extermination inside the barbed wire.

Accounts of the Somme, Keegan continues, produce in readers and audiences 'much the same range of emotions as do the descriptions of the running of Auschwitz':

guilty fascination, incredulity, horror, disgust, pity and anger - and not only from the pacific and tender-hearted; not only from the military historian on whom, as he recounts the extinction of this brave effort or that, falls an awful lethargy, his typewriter keys tapping leadenly to drive the lines of print,like the waves of a Kitchener battalion failing to take its objective, more and more slowly towards the foot of the page. $\underline{(8)}$

One problem for the pre-Middlebook historian Keegan identifies was the shortcomings of many post-war regimental histories. There were excellent regimental histories in which the official daily record, the unit War Diary, was 'supplemented and illuminated' by personal reminiscence from 'literate and articulate 
survivors'. But such histories tended to be those of the London Territorial regiments, which had a strong and established sense of identity, a middle-class character and personal connections with metropolitan journalism and publishing.

The Regular Army battalions of the Guards and other regiments of the line were also able to update their histories, but the Somme was 'predominantly a battle of humbler and more transient groups'. The Regular regiments to which the greatest number of 'service' (wartime volunteer) battalions were attached were often the least affluent and based further from London, and so tended to be of lower social status and have fewer monied officers. Regiments such as these were less able to produce exhaustive regimental histories.

Then there was the problem with sources.

During the war, it was the job of the intelligence officer to update the battalion War Diary daily. If, however, that officer were an amateur (and most Kitchener officers were in 1916) the diary entries might be sketchy. If the action was intense and casualties heavy, the War Diary might be days in arrears and written up hastily 'for form's sake from a single, sometimes second-hand memory of events'. Thus, notwithstanding all the corpses, the opportunity of leaving a fitting record of 'Kitchener Mob' experience could have been lost, especially as the survivors of the Somme began to fade away.

Before this happened a Lincolnshire farmer, Martin Middlebrook, in whom a chance visit to the war cemeteries of the Somme in the late 1960s had aroused an obsessive curiosity about the nature and fate of the Kitchener armies, embarked on a quest to discover survivors of 1 July, and in a truly heroic effort of historical fieldwork, found and interviewed 546 of them, the majority (with the exception of a few who were under age when they enlisted) men of 70 or over.(9)

The result was what Keegan views as a 'remarkable' achievement', comparable with that of William Siborne in interviewing survivors of Waterloo, although Middlebrook is 'a great deal more readable'.(10)

Siborne, however, concentrated on officers in order to piece together his 'meaningful' account of Waterloo, whereas Middlebrook's answers came from the junior and other ranks. Middlebrook also interviewed German as well as British and Commonwealth survivors (although not French, as he was not interested in the French-held section of the line.(11)

The individual experience of the Middlebrook interviewees was very local, yet Keegan avers, collectively depicted 'almost indecipherable chaos'. This helps explain why one wave of volunteer youngsters after another was sent forward to be shot down in their turn. Next to nobody in authority at the front could see what was going on in the smoke and din, and even if had they been able to, telephone and telegraph communications were not up to reporting 'upstairs' and to receiving and passing on any amended orders. 'What Middlebrook's evidence emphasizes', Keegan concludes, 'is the extent to which a hundred years of technological advance had further reduced the range of effective vision on the battlefield, particularly in those not familiar with the realities of war'.

Although Middlebrook offers perspective on the whole battle, his focus was on reconstructing the 'first day', calmly setting it in the perspective of the political and strategic imperatives of the time. He blended his vast haul of survivors' reminiscences with existing archive material to produce what was then novel, a 'bottomup' history that followed the men on the ground throughout the day, instead of the customary 'top-down' narrative told from the point of view of the generals and the politicians. Middlebrook had 'humanized' an army and a battle.

Middlebrook drove forward his even-handed broader narrative by interweaving it with the detailed story of ten men, seven of whom were to survive $1 \mathrm{July}$. A clue as to how he hit upon this compelling device may lie in the last of the 22 entries in the book's slender bibliography, 'John Harris, Covenant with Death (fiction) (London, 1969)'. 
Harris, the son of a Somme veteran, published his novel in 1961, its mainspring being a Kitchener volunteer's account of the raising, training and destruction of his battalion on the Somme. The account appears to be based upon what happened on 1 July 1916 to the Sheffield City Battalion (12th Bn., York \& Lancaster Regiment) in the attack on Serre. Their casualties for the day were 512: over half the men who attacked.

Middlebrook himself recently (2014) recalled how as a young man he had been overwhelmed by the 'density' of military cemeteries on the Somme. At one point on his first visit (1967) he could see four without having to move. Noting how many men had been killed on the same day, 1 July, he said to his wife (the late Mary Middlebrook) 'I'm going to write a book, the first day of the battle of the Somme'. He thinks of that work and his many subsequent books of military history on 20th-century warfare as 'writing the sort of things about ordinary people that ordinary people like to read'. He began work on The First Day on the Somme by sketching a synopsis on the back of a programme for an Egg Marketing Board exhibition while on the train journey back from Olympia to Boston. $\underline{(12)}$

In The Face of Battle, Keegan sought to recreate the direct experience of individuals at 'the point of maximum danger'. He does so with reference to three battles, two of them - Agincourt and Waterloo nationally celebrated as victories. The third - the Somme (all 141 days of it) - had long been assumed by many, including some popular historians, as a national calamity. 'The Somme' is still regarded equivocally although since Middlebrook and Keegan's books were published the pendulum has swung towards the view that the battle was a qualified victory.

Before 1971 and for some time afterwards, however, it was not the Somme but the (1917) Third Battle of Ypres (or 'Passchendaele') that was widely seen as typifying the horrors of the Great War's industrial-scale slaughter. Keegan's book played a part in that change. In view of his encomium on Middlebrook's research, moreover, it could appear that this influenced Keegan in plumping for the Somme rather than for Passchendaele as the third of his chosen battles. The Somme also fitted The Face of Battle better than Passchendaele in the sense that Agincourt and Waterloo, like the Somme, were battles whose time and place were forced upon their commanders, whereas Passchendaele was not. Either way, The Face of Battle helped to further the interest that Middlebrook had helped arouse in Somme studies.

When American academic Fred R. van Hartesveldt published a historiography and annotated bibliography of the Somme in 1996, he marked Middlebrook more highly for research than previous 'critical surveys' such as the novelist John Harris's own The Somme: Death of a Generation.(13)

Van Hartesveldt also praises Middlebrook's grasp of the strategic and tactical realities of the day. Asked 'How much of the slaughter [on the Somme] resulted from the callousness of the high command in despatching troops into futile battles?' Middlebrook, who freely confesses to the advantages of hindsight, replied 'It wasn't as simple as that. It just happened.' It was something 'completely unexpected', and to break through the German lines and end the war 'beyond anybody's capability'. The standard method was for the attacking infantry, under cover of shell fire, 'to get as close to the enemy trenches as possible and rush in'. This wasn't 'callousness', so much as 'an inbred belief that's how it should be and that's how he [Sir Douglas Haig, Commander in Chief of the British Expeditionary Force on the Western Front] was jolly well going to do it'.

A British bibliographer, Gerald Gliddon, remarks of The First Day on the Somme that while it was 'acclaimed as a masterly account' it was 'often criticized for concentrating on one day'.(15) Middlebrook, however, returned to this approach with The Kaiser's Battle (16), his account of the opening day of the March 1918 German counter-offensive, for which he also repeated his technique of interviewing British and German veterans while it was still possible to do so. The Allied riposte ended in a hurricane of victories that saw the total defeat and surrender of Germany, but the 1918 campaign has yet to resonate with the British to the same extent as that of 1916. Still, Middlebrook's interviews and book on the conclusive 1918 campaign 
are there on the shelf to be reached for as that centenary year dawns.

\section{Notes}

1. E.g. William Philpott, ' A classic of military history', in Bloody Victory: The Sacrifice on the Somme and the Making of the Twentieth Century (London, 2009), p. 697.Back to (1)

2. Gary Sheffield, The Somme (London, 2003), pp. xii-xiii.Back to (2)

3. Sheffield's other 'foundation stone' is Robin Prior \& Trevor Wilson, Command on the Western Front (Oxford, 1992). Back to (3)

4. Sheffield, The Somme, p. xiii.Back to (4)

5. In conversation with the writer.Back to (5)

6. Sheffield, The Somme, 'Foreword', p. x.Back to (6)

7. Gary Sheffield, Forgotten Victory - The First World War: Myths and Realities (London, 2001).Back to (7)

8. John Keegan, The Face of Battle: A Study of Agincourt, Waterloo and the Somme (London, 1976), pp. 255-8.Back to (8)

9. IWM Documents 26137. The men were 'interviewed' in the sense of being invited to fill in and return a standard questionnaire which had space for additional comment. Where necessary, respondents were then spoken to in person. The Felix Fund charity for bomb-disposal personnel and their families lodged a substantial part of Middlebrook's archive for The First Day on the Somme and his subsequent The Kaiser's Battle with the Imperial War Museum in 2016.Back to (9)

10. William Siborne, The Waterloo Campaign 1815 (London, 1904).Back to (10)

11. The French line straddled the Somme river; the British named the battle for their section of the front after the departement of the Somme.Back to (11)

12. In conversation with the writer.Back to (12)

13. Fred R. van Hartesveldt, The Battles of the Somme, 1916: Historiography and Annotated Bibliography (Westport, CT, 1996); John Harris, The Somme: Death of a Generation (London, 1966).Back to (13)

14. http://ottawacitizen.com/news/local-news/qa-martin-middlebrook [2]> [accessed 5 October 2016]. Back to (14)

15. Gerald Gliddon, The Battle of the Somme: A Topographical History (Stroud, 1996).

16. Martin Middlebrook, The Kaiser's Battle (London, 1978).Back to (15)

\section{Other reviews:}

Bibliography of British and Irish History

http://blog.history.ac.uk/2016/09/the-battle-of-the-somme-have-you-seen-the-big-push-films/ [3]

Source URL:https://reviews.history.ac.uk/review/2000

\section{Links}

[1] https://reviews.history.ac.uk/item/248907 [2] http://ottawacitizen.com/news/local-news/qa-martinmiddlebrook [3] http://blog.history.ac.uk/2016/09/the-battle-of-the-somme-have-you-seen-the-big-pushfilms/ 